\title{
PRELIMINARY STUDIES REVEAL RICHNESS OF CARNIVOROUS PLANTS IN AN UNDEREXPLORED AREA OF NORTHEASTERN BRAZIL
}

\author{
Caio Vinicius da SiLVA • Universidade Federal da Paraíba • João Pessoa • Paraíba State • Brazil • \\ caioviniciusgba@hotmail.com
}

Brazil is home to several carnivorous plant genera, including Drosera, Genlisea, Utricularia, Heliamphora, Philcoxia, Catopsis, and Brocchinia. It is only second to Australia (c. 188 species) (Bourke \& Nunn 2012; Darnowski et al. 2006; Schlauer 2013) in total number of carnivorous plant species, with approximately 125 (Forzza et al. 2010; Schlauer 2013).

The majority of carnivorous plant species in Brazil are found in campo rupestre vegetation, mostly along the Cadeia do Espinhaço highlands of Minas Gerais and Bahia states, as well as in savanna areas of central Brazil. Another habitat that is rich in carnivorous plant species is found along coastal areas and is known as restingas (Rivadavia 2002), which occur all along the $c .8500$ $\mathrm{km}$ of coastal Brazil.

Since September 2010, I have been researching Droseraceae and Lentibulariaceae in the state of Paraíba, northeastern Brazil. More specifically, my studies involve ecology and taxonomy of carnivorous plants found along the coastal regions of Paraíba (Fig. 1).

In Paraíba, carnivorous plants occur mainly in "tabuleiro" habitats (Fig. 2), which consist of savanna vegetation (similar to the "cerrado" common to central Brazil), growing over leached sandy soils with numerous natural springs. Tabuleiros are found along the coast of northeastern Brazil and have distinct wet and dry seasons, with temperatures around $15-29^{\circ} \mathrm{C}$ in the wet season (March to September) and $25-45^{\circ} \mathrm{C}$ in the dry season (October to February).

Over the past 3 years, I have observed 19 species of carnivorous plants in different regions of eastern Paraíba (Fig. 3 and 4): Utricularia amethystina Salzm. ex A.St.-Hil. \& Girard, U. foliosa L., U. gibba L., U. guyanensis A.D.C., U. juncea Vahl, U. nana A.St.-Hil. \& Girard, U. nigrescens Sylvén, Utricularia olivacea C.Wright ex Griseb., U. pusilla Vahl, U. simulans Pilg., U. subulata L., U. tenuissima Tutin, U. trichophylla Spruce ex Oliv., U. tricolor A.St.-Hil., U. triloba Benj., Genlisea filiformis A.St.-Hil., G. repens Benj., Drosera communis A.St.-Hil., D. sessilifolia A.St.-Hil.

Many of the above species were found growing sympatrically at the numerous sites I have studied. I will give brief descriptions below for each of these species, with a few details on morphology

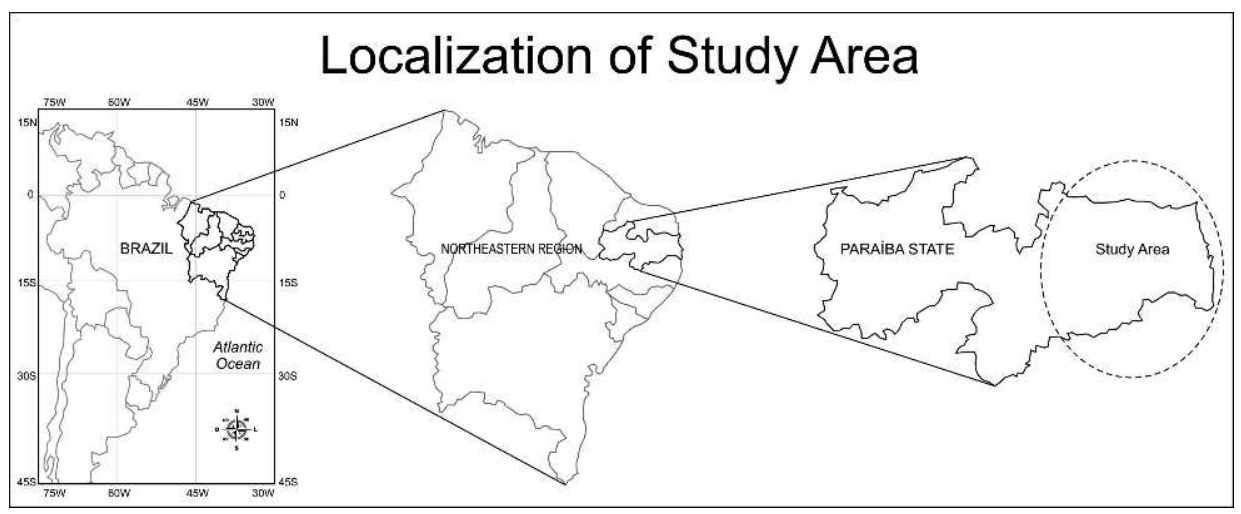

Figure 1: Brazil, northeastern Brazil, and Paraíba State. 


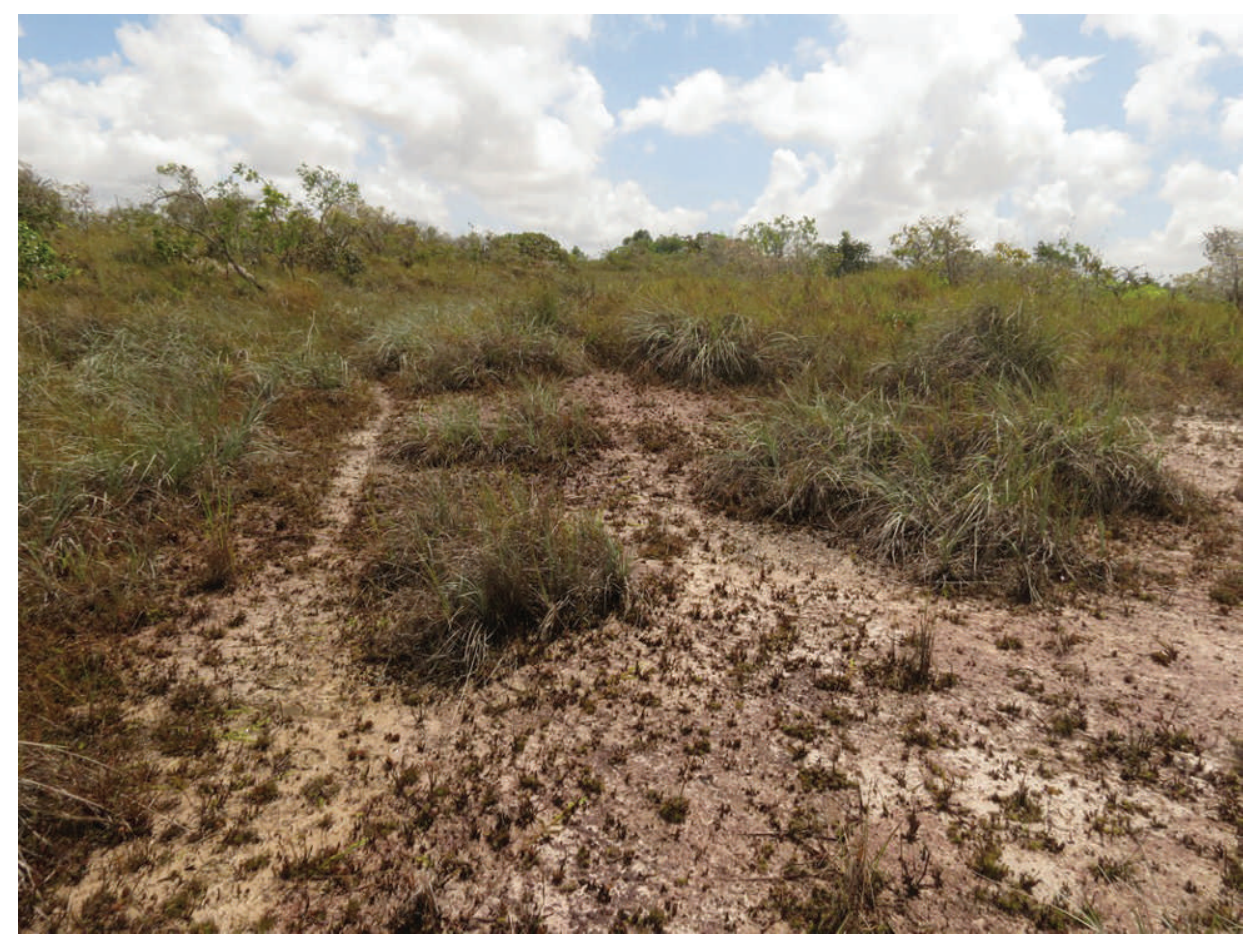

Figure 2: Area of tabuleiro habitat.

and the habitats where I observed each in Paraíba. Collections of majority species mentioned above were deposited at JPB Herbarium (Herbário Lauro Pires Xavier) of the Universidade Federal da Paraíba in João Pessoa and are part of my master degree program.

Utricularia amethystina (Fig. 4C) is distributed throughout tropical and subtropical America. In Brazil it is widespread in all but the southernmost states, and is relatively rare in the north and northeast (Taylor 1989). In Paraíba this species occurs abundantly in areas distant about $20 \mathrm{~km}$ from the coast, between $150 \mathrm{~m}$ and $180 \mathrm{~m}$ elevation, where it inhabits moist sandy soils, usually near watercourses, forming large populations. This is a highly-variable taxon with flowers varying from purple-blue to white to yellow (Taylor 1989), and will very likely be divided into multiple species in the following years. The local Paraíba form has flowers that are $0.5-1.5 \mathrm{~cm}$ long, blue-purple with yellow and white at the base of the lower lip, borne on long stalks measuring $4-16 \mathrm{~cm}$ in height, and it grows both as an annual and as a perennial. Its leaves are rounded, often occurring in small rosettes and commonly shaded by grasses.

Utricularia foliosa (Fig. 5) is another widespread species known from Africa, North and South America, occurring throughout most of Brazil (except in the southernmost states) (Taylor 1989). In Paraíba I have only personally observed this large aquatic perennial species growing abundantly in a lake about $40 \mathrm{~km}$ from the coast at $200 \mathrm{~m}$ elevation. The flowers are bright yellow, borne on scapes $10-30 \mathrm{~cm}$ in height, the stolons reaching $2 \mathrm{~m}$ in length.

Utricularia gibba (Fig 3D) is one of the most common Utricularia species in Paraíba and is abundant all over Brazil - as well as being one of the most widespread carnivorous plant species in the world, with pantropical distribution (Taylor 1989). I have so far found this perennial aquatic at 6 locations, in streams and lakes ranging 10-100 km from the coast at elevations ranging from 20-300 


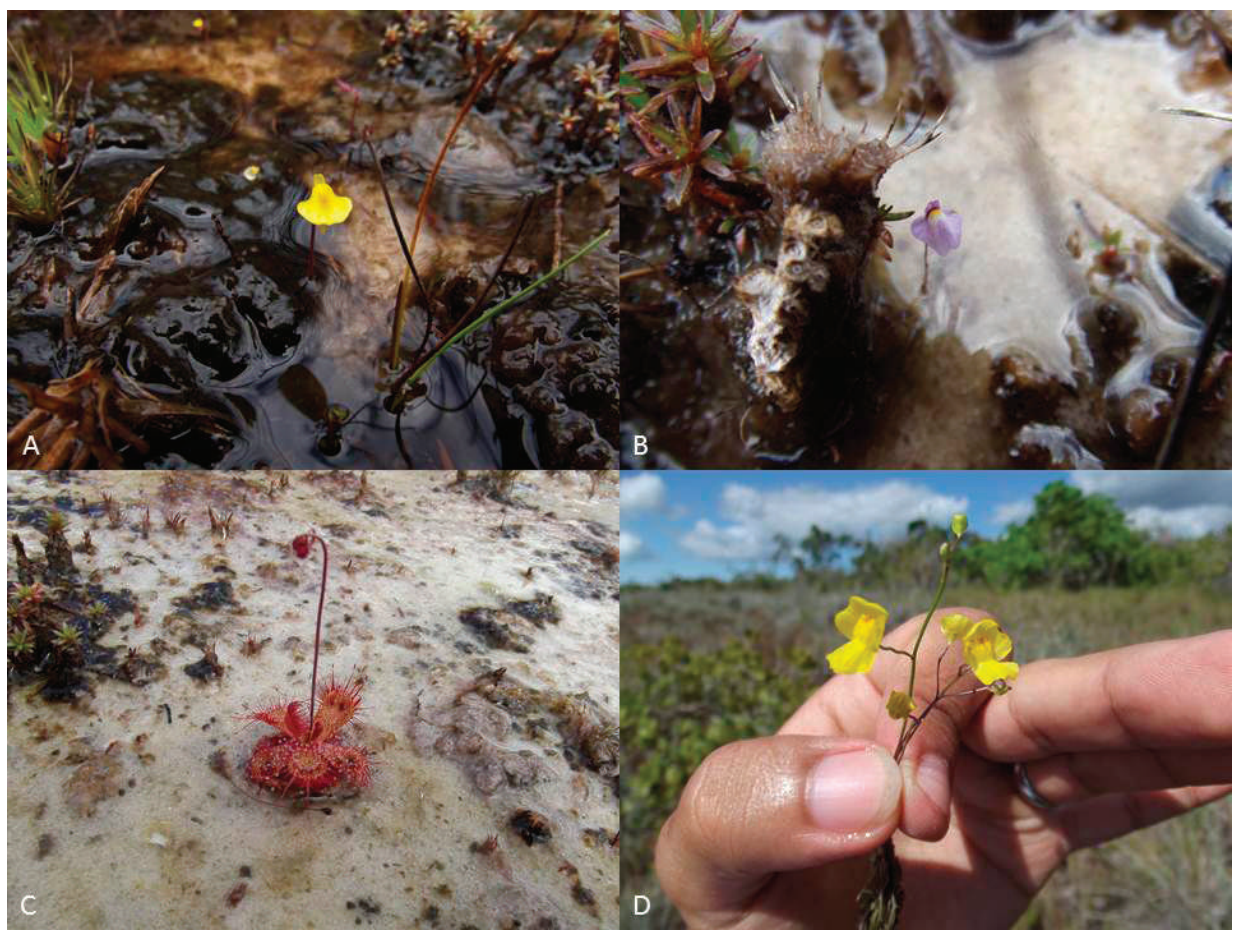

Figure 3: A) Utricularia nana; B) U. tenuissima; C) Drosera sessilifolia; D) U. gibba.

$\mathrm{m}$, usually forming extensive populations. Utricularia gibba has thread-like leaves and I observed yellow flowers measuring $0.5-2 \mathrm{~cm}$ in diameter on inflorescences measuring $4-7 \mathrm{~cm}$ tall. It grows in full sun as a semi-aquatic on wet soil bordering bodies of water.

Utricularia guyanensis is a widespread but relatively rare terrestrial annual species known to occur in Central and South America, including the northern half of Brazil. It was placed in its own monotypic section by Taylor, sect. Stylotheca, mostly because of its unique elongated style and stamens (Taylor 1989). I encountered U. guyanensis in an area of environmental preservation near the coast at $20 \mathrm{~m}$ elevation, growing in sandy soils that dry out completely in the dry season. The inflorescences were deep red, measuring $7-15 \mathrm{~cm}$ tall, and the flowers a golden yellow color, $1-2 \mathrm{~cm}$ long.

Utricularia juncea is common across eastern North America, Central America, and northern South America, occurring in northern and northeastern Brazil (Taylor 1989), and apparently grows both as an annual and as a perennial. In Paraiba, I found $U$. juncea growing in areas about $20 \mathrm{~km}$ from the coast at $150 \mathrm{~m}$ elevation, occurring in wet sandy soil. The yellow flowers measured around 1-2 $\mathrm{cm}$ long on scapes 7-18 cm high.

Utricularia nana (Fig 3A) is a small perennial species occurring in Guyana, Suriname, Venezuela, and throughout all regions of Brazil (Taylor 1989). It inhabits wetlands in Paraíba, c. $20 \mathrm{~km}$ from the coast and $150 \mathrm{~m}$ elevation and I observed yellow flowers measuring $0.5-1 \mathrm{~cm}$ long on scapes 1-3 $\mathrm{cm}$ high. Taylor placed this species in its own monotypic section, sect. Benjaminiana (Taylor 1989). It grows under full sun in wet sandy soil.

Utricularia nigrescens (Fig. 6A) is an annual species very similar to U. pusilla (but larger) and endemic to Brazil, where it occurs mainly in the central region (Taylor 1989). I discovered the first population occurring in northeastern Brazil (Forzza 2010), growing at $180 \mathrm{~m}$ elevation in sandy soil 


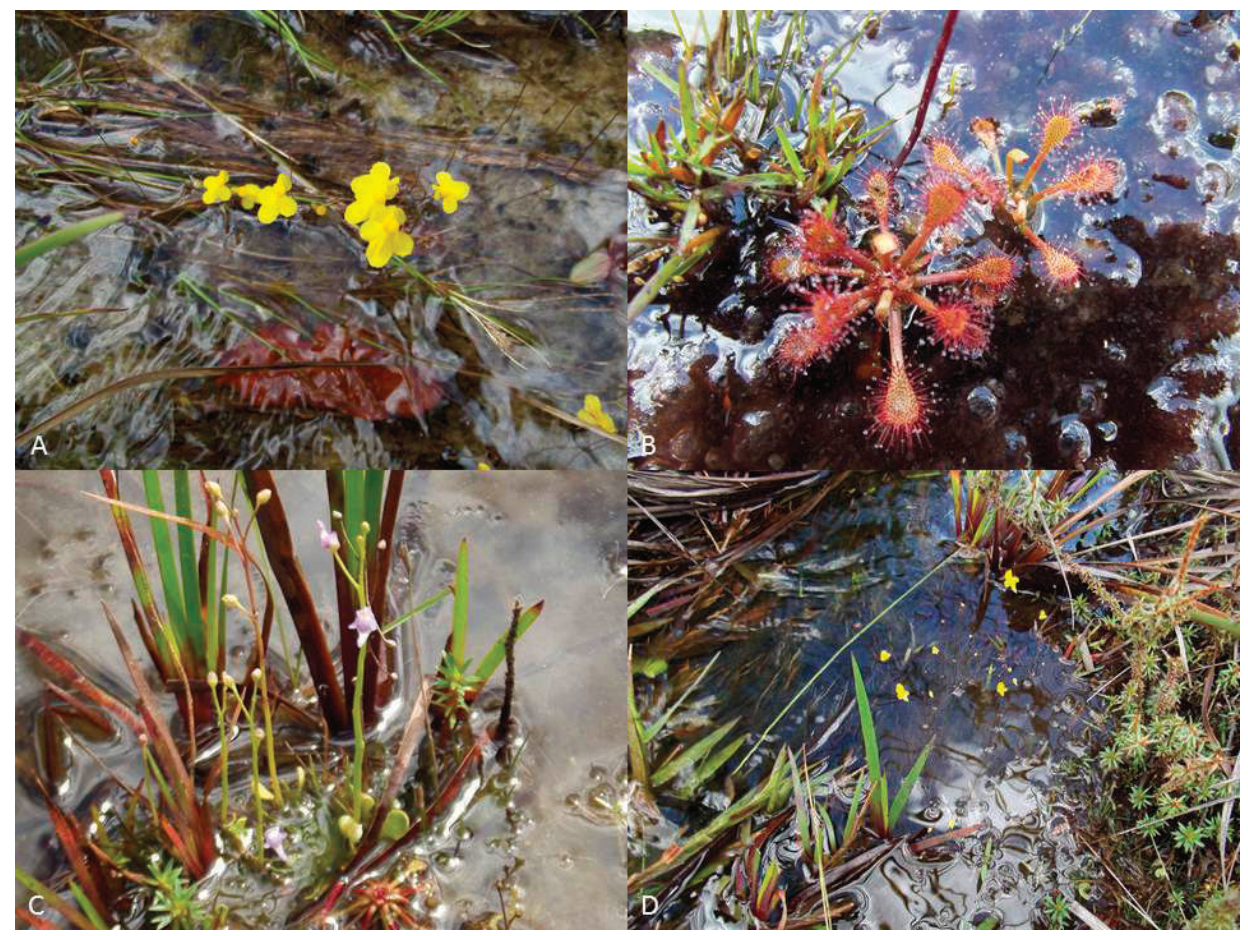

Figure 4: A) Utricularia triloba Benj.; B) Drosera communis A.St.-Hil.; C) U. amethystina Salzm. ex A.St.-Hil. \& Girard; D) U. subulata L.

of a flooded area near a spring c. $25 \mathrm{~km}$ from the coast of Paraíba, with yellow flowers measuring $1-1.5 \mathrm{~cm}$ long and scapes $2-4 \mathrm{~cm}$ high.

Utricularia olivacea is an aquatic species and also the smallest among the Utricularia taxa found in Paraíba. This was the first record of U. olivacea in northeastern Brazil (Forzza 2010). The flowers were cream-colored and translucent, measuring only about $0.5 \mathrm{~cm}$ in diameter, borne on scapes around $1 \mathrm{~cm}$ high. I only found a few specimens inhabiting wetlands about $20 \mathrm{~km}$ from the coast, growing in the semi-shade of grasses in a thin film of water over wet soils. When I returned to this location in the dry season, the habitat was completely dry, thus $U$. olivacea appears to grow as an annual at this site.

Utricularia pusilla is widespread in Central and South America, occurring in Brazil throughout most of the country, except the southernmost states (Taylor 1989). This annual was also not previously recorded from the state of Paraíba until I collected it in 2012, between 150-180 m elevation, $c$. $20 \mathrm{~km}$ from the coast. I found it growing in flooded areas near streams, in wet sandy soils exposed to full sun. The yellow flowers measured around $1 \mathrm{~cm}$ long on scapes around 2-4 cm high.

Utricularia simulans is found in tropical Africa as well as in the Americas, from Florida to Paraguay and southern Brazil, where it is one of the most abundant and widespread Utricularia species (Taylor 1989). In Paraíba it occurs in areas around 50-180 m elevation, between 5-20 km from the coast, where it inhabits humid sandy soils under full sun and grows as an annual. The flowers I observed were a golden yellow in color, measuring around $0.5-1 \mathrm{~cm}$ long on scapes 2-6 cm high. 


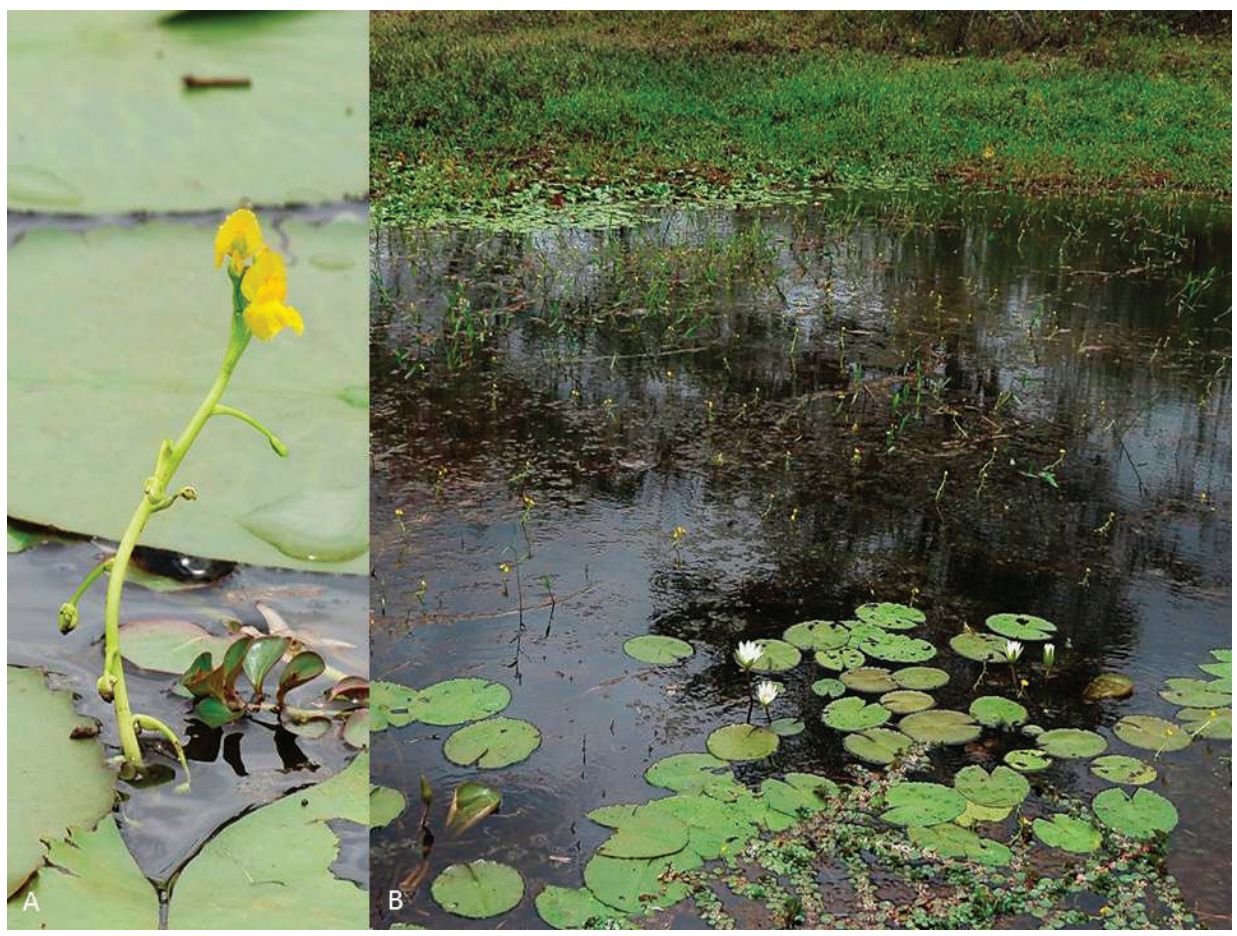

Figure 5: A) Utricularia foliosa L.; B) Lake habitat of U. foliosa.

Utricularia subulata (Fig 4D), not surprisingly, is the most abundant of all Utricularia along the coast of Paraíba, occurring in sandy soils and wetlands under full sunlight. It is a pantropical species, the most widespread of all Utricularia worldwide and is distributed throughout Brazil (Taylor 1989), where it grows both as an annual and as a perennial. I observed yellow flowers measuring about $1 \mathrm{~cm}$ long on scapes around 2-10 $\mathrm{cm}$ high.

Utricularia tenuissima (Fig. 3B) is a rare species, although widespread in South America, known from Brazil, Colombia, Venezuela, Suriname, Trinidad, and Guyana (Taylor 1989). In Paraíba I found it c. $20 \mathrm{~km}$ from the coast at $150 \mathrm{~m}$ elevation, where it likely grows as an annual. This was the first record of U. tenuissima in northeastern Brazil (Forzza 2010). The few tiny flowers encountered were lilac, the base of the lower lip colored white and yellow, measuring about $0.2-0.5 \mathrm{~cm}$ long on scapes only $0.5-1 \mathrm{~cm}$ high (Taylor 1989). These were growing in wetlands surrounding natural springs, semi-shaded by grasses in wet soils.

Utricularia trichophylla is another new discovery for the state of Paraíba, which I encountered between 150-180 m elevation, c. $20 \mathrm{~km}$ from the coast. It is known to occur in Guyana, Venezuela, and throughout most of Brazil, except in the southernmost states (Taylor 1989). No flowers were observed, only the filiform green leaves submerged along shady margins of a stream. Although described as a perennial species by Taylor (1989), I returned to this same site a few months later and it was completely dry, suggesting $U$. trichophylla may grow as an annual too.

Utricularia tricolor is a widespread species occurring from northern Argentina to Venezuela, showing great morphological variability in overall size and flower color, sometimes overlapping with the closely related U. amethystina in some characters (Taylor 1989). In Paraíba it grows both as 


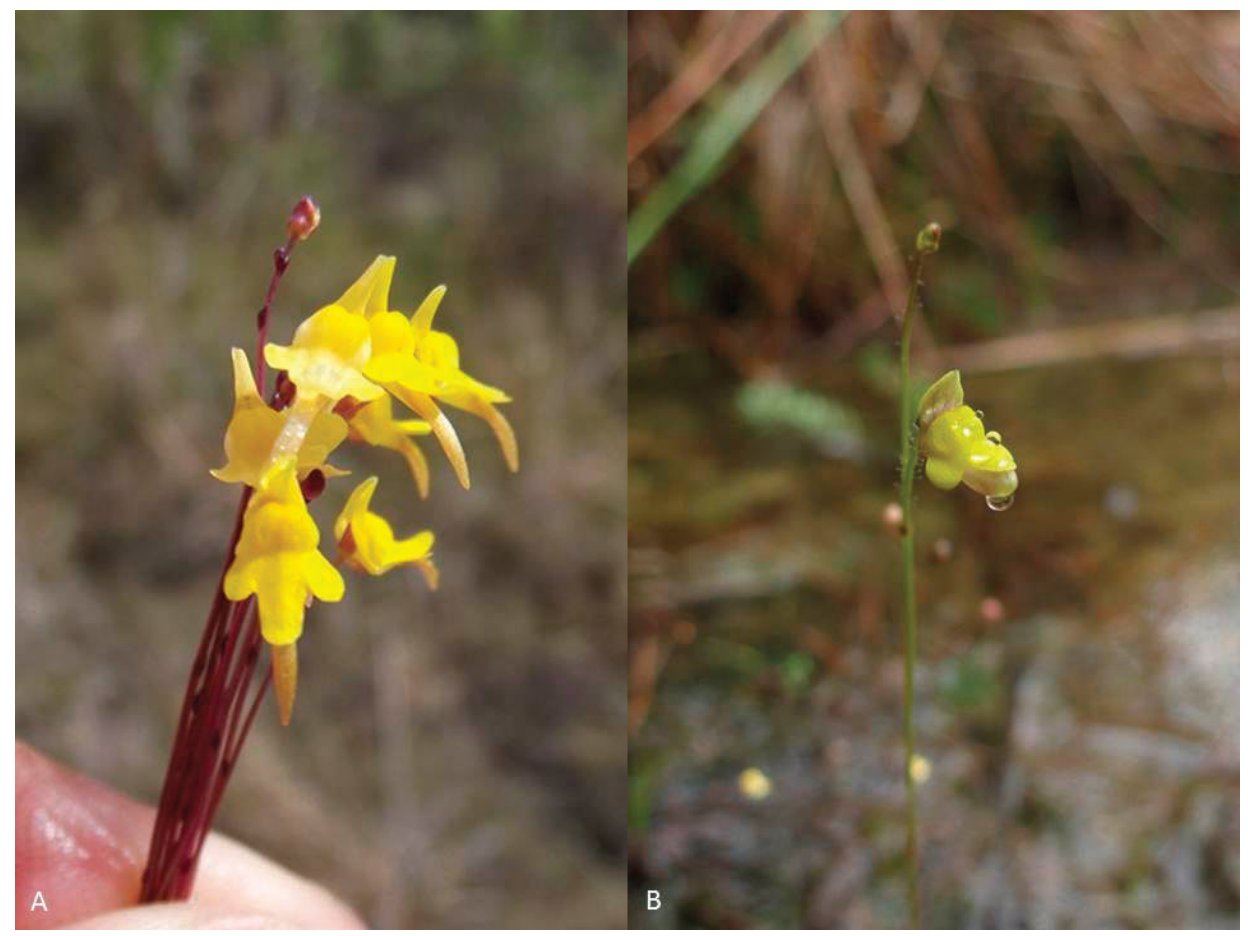

Figure 6: A) Utricularia nigrescens Sylvén; B) Genlisea filiformis A.St.-Hil.

an annual and as a perennial, occurring in wet to dry sandy soils among sparse grasses. The flowers observed were lilac with the base of the lower lip colored in yellow and white, measuring $1.5-2 \mathrm{~cm}$ in length, on scapes 5-8 cm high.

Utricularia triloba (Fig. 4A) was one of the first carnivorous plants I ever found in Paraiba, in 2010, and it was also the first time this species was collected in this state. It is distributed in Central and South America, including most of Brazil except the southernmost states (Taylor 1989). In Paraíba I observed it growing under full sun in sandy soils dry or humid at several places along the coast. Utricularia triloba is very similar to U. subulata, but is most easily distinguished by the three projecting nerves on the sepals (Taylor 1989). It grows both as an annual and as a perennial and was observed with yellow flowers measuring around $1-1.5 \mathrm{~cm}$ in length on scapes $5-10 \mathrm{~cm}$ high.

Genlisea filiformis (Fig. 6B) was found growing at a few locations in seasonally wet sandy soils near water courses. This is the most widespread of all Genlisea species, occurring over most of Brazil (except the southernmost states), as well as in other countries of northern South America and Central America (including Cuba), even extending into southern Mexico (Taylor 1991). In Paraíba I have found this annual species in areas between 150-180 m elevation, c. 20-25 km from the coast, bearing creamy-yellow flowers measuring $0.4-0.7 \mathrm{~cm}$ long on scapes 4-9 $\mathrm{cm}$ high.

Genlisea repens was also not recorded from Paraíba state until I collected it in 2012. This widespread and common perennial species occurs in Venezuela, Guyana, Paraguay, and throughout Brazil (Taylor 1991), but was previously unknown from coastal habitats. I observed it occupying a large area c. $20 \mathrm{~km}$ from the coast at 150-180 m elevation, where it is locally abundant and forms an extensive population in sunny flooded sandy areas along streams. All the flowers observed at this 
site were creamy-yellow with only the base of the lower lip colored in the more typical bright yellow, measuring around $0.5-1 \mathrm{~cm}$ long on scapes around 4-6 $\mathrm{cm}$ high.

Drosera communis (Fig. 4B) is a perennial species widely distributed in Brazil and neighboring Venezuela, Bolivia, and Colombia (Diels 1906; Dawson 1938; Maguire \& Wurdack 1957; Correa \& Silva 2005). Although common in highlands above c. $500 \mathrm{~m}$ elevation in Brazil, this species strangely occurs along coastal habitats from Paraíba to northern Bahia (Silva 2007). In Paraíba it was observed in wetlands near springs c. 5-20 km from the coast, between 20-180 m elevation, forming small populations under full sun. The reddish leaves measured around $0.5-1.5 \mathrm{~cm}$ in length and the white flowers were about $1 \mathrm{~cm}$ in diameter, borne on scapes measuring around $5-12 \mathrm{~cm}$ high.

Drosera sessilifolia (Fig. 3C) is widely distributed in northern South America, including most of the northern half of Brazil as well as Venezuela and Colombia (Correa \& Silva 2005). In Paraíba, this annual species occurs in areas 20-30 km from the coast, between 140-200 m elevation, forming both small and large populations under full sun in seasonally wet sandy soils or wetlands. The leaves are yellow-green to orange-green in color, measuring around $1-3 \mathrm{~cm}$ in length, and the pink flowers are about $1 \mathrm{~cm}$ in diameter, borne on scapes $10-30 \mathrm{~cm}$ high.

Acknowledgements: I would like to thank my friend Fernando Rivadavia for his help in supporting my research and for nurturing carnivorous plant enthusiasm in Brazil.

\section{References}

Bourke, G., and Nunn, R. 2012. Australian Carnivorous Plants. Redfern Natural History Productions, Poole, UK.

Correa, M.D., and Silva, T.R.S. 2005. Drosera (Droseraceae). Flora Neotropica, Bronx, v. 96, nov. p. 1-65.

Darnowski, D.W., Carroll, D.M., Płachno, B., Kabanoff, E., and Cinnamon, E. 2006. Evidence of protocarnivory in triggerplants (Stylidium spp.; Stylidiaceae). Plant Biology 8(6): 805-812.

Dawson, G. 1938. Las especies del género Drosera e la flora Argentina. Rev. Arg. Agron. 5: 231239.

Diels, L. 1906. Droseraceae. In: Engler, A. (ed.). Das Pflanzenreich - Regni vegetabilis conspectus. Leipzig: Wilhelm Engelmann. p. 1-137.

Forzza, R.C., et al. (Org.) 2010. Catálogo de plantas e fungos do Brasil. Rio de Janeiro, Andrea Jakobsson Estúdio, Instituto de Pesquisas Jardim Botânico do Rio de Janeiro, v. 2.

Honda, M. 2012. Carnivorous Plants Distribution Map. http://www.honda-e.com/A02_World\%20 Maps/CPWorldMap1.htm, accessed 20 October 2012.

Maguire, B., and Wurdak, J.J. 1957. The botany of the Guayana Highland - part II. Mem. N. Y. Bot. Gard. 9(3): 331-337.

Moraes, D. n.d. Bioma Costeiro. http://www.invivo.fiocruz.br/cgi/cgilua.exe/sys/start.htm?infoid= $967 \&$ sid=2, accessed 08 June 2013.

Silva, T.R. 2007. Flora da Bahia - Droseraceae Salisb. Sitientibus Série Ciências Biológicas. 7(4): 393-397.

Taylor, P.G. 1989. The genus Utricularia - a taxonomic monograph. Kew Bulletin Additional. Series XIV. HMSO, London.

Taylor, P. 1991. The genus Genlisea. Carniv. P1. Newslett. 20(1-2): 20-26. 